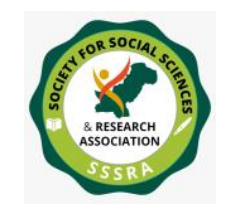

Pak. Journal of Int'L Affairs, Vol 4, Issue 3 (2021) Livestock Management Practices: Socioeconomic ...

\title{
LIVESTOCK MANAGEMENT PRACTICES: SOCIOECONOMIC IMPACTS IN BALOCHISTAN
}

\author{
Dr Abdul Rehman \\ Senior Veterinary Officer \\ Livestock and Dairy Development Department \\ Quetta - Pakistan \\ ziaratreman@yahoo.com \\ Dr Arslan Maqbool \\ Veterinary Officer \\ Livestock and Dairy Development Department \\ Quetta - Pakistan \\ arslanmaqbool81@gmail.com \\ Dr Abdul Sattar \\ Senior Veterinary Officer \\ Livestock and Dairy Development Department \\ Quetta - Pakistan \\ sattar_baloch40@yahoo.com
}

\begin{abstract}
This research was conducted into two districts of Balochistan such as Lasbela and Loralai so as to determine the livestock management practices within terms of socioeconomic acceleration. A descriptive design was applied so that it obtained the views of livestock farmers. Three hundred livestock farmers randomly selected, 150 from each district. A closed-ended questionnaire was developed. Non-parametric test was used. Results show that Most (34\%) of livestock farmers age ranged into the 31 to 40 years. Half 50\% of the livestock farmers were illiterate and did not get their education from any formal institution. Vast majority $77 \%$ of the livestock respondents were male by gender. Non-significant relationships between the variables were found regarding socio-economic impacts based on ( $p<.05)$ alpha level. It was recommended that the latest technologies related to the livestock sector must be prompted at province level. So as to improve the livelihood options of the respondent's adequate




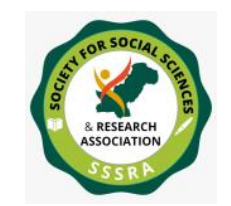

Pak. Journal of Int'L Affairs, Vol 4, Issue 3 (2021) Livestock Management Practices: Socioeconomic ...

subsidy rate of animal fodders, animal medicines, animal shelters provided to the livestock farmers by the government. For the department adequate incentives should be given to the staff so that to increase the competency level of livestock department staff. Furthermore, the government should provide livestock farmers satisfactory information so as to give livestock farmers fair share in consumer prices and legitimate trade practices adopted. Livestock extension services in this regard disseminated modern animal husbandry practices to the livestock farmers.

Keywords: Management practices, Livestock sector, Socio-economic impacts, Selected districts, Balochistan.

\subsection{Overview}

Livestock is a major pillar of rural development in Pakistan. Livestock sector is the major source for foodstuff and contributes to the country's GDP. Vast majority of the rural poor directly or indirectly depend on this sector for his/her socio-economic enchantment. Consequently, livestock are major food drivers and food sources for rural people (ADB, 1989; and ADB, 1987).

On the other hand, this sector is one of the foremost fonts for the elimination of rural poverty. Due to its potential and prospective this sector has a major factor to cash income for the powerless people in rural areas. At country level this sector delivers equally compost manure as well as draught power for farming. However, this sector also provides the animal dung for domestic cooking in rural areas as a major heat source also. On the other hand, this sector provides milk or dairy products for human intake (Asian Development Bank, 2004).

Understanding of expected socioeconomic impacts in this regard has usually been constrained through aspiring, like top-down style in livestock sector, nonexistence emphasis on livestock ownership, interruptions in various livestock project initiation; poor animal health condition, less production, ineffective livestock extension activities and very poor performance of this sector. However, these limiting factors reflected the negative impact in the livestock sector at a greater extent (Asian Development Bank, 2004).

Livestock sector at the country level was faced with severe challenges, these obstacles limited the role of this sector. In this regard, the effective linkage among livestock production and other related factors were strengthened. Therefore, it was observed that the livestock sector is one of the most suitable drivers for food security as well as eliminating 
rural poverty. These livestock management practices have significantly impacted the socioeconomic condition of the rural masses (Asian Development Bank, 2004).

In the Pakistani economy, livestock plays a noteworthy role after the agricultural sector. The livestock sector is the foremost segment for the rural economy and identifies the positive socio-economic impacts and major contributors after the agriculture sector. Majority of rural people and their livelihood option related to this sector (Simon, 1980).

Dairy products on the other hand, has major business in rural areas and rural communities in this regard, sustainable rural development based on the livestock sector. So the federal government developed a well mechanism to export the dairy product so that it could boost the rural community's income. However, the livestock sector in the developing countries is the fastest-growing sub-sectors in this context. However, the livestock sector is to fulfill the daily diet of rapid urban development. In Pakistan the red meat consumption pattern has increased rapidly (Delgado, 2005; and Meadowcroft, 2009).

Livestock sector it was estimated that there more than thirty-five million people engaged as a labor force. More potential of the livestock animals is existing in Sindh and Punjab in the period of 2020. It was also estimated that 78.2 million of goats, 49.6 million of cattle, 41.2 million of buffaloes and 30.9 million sheep existed in Pakistan in the period of the 2020 as shown in figure-1 (Siddiqi, 1977; Encyclopedia of the Nations, 2011; and Wasim, 2020).

Figure-1, Total population of livestock animals in Pakistan, 2020.

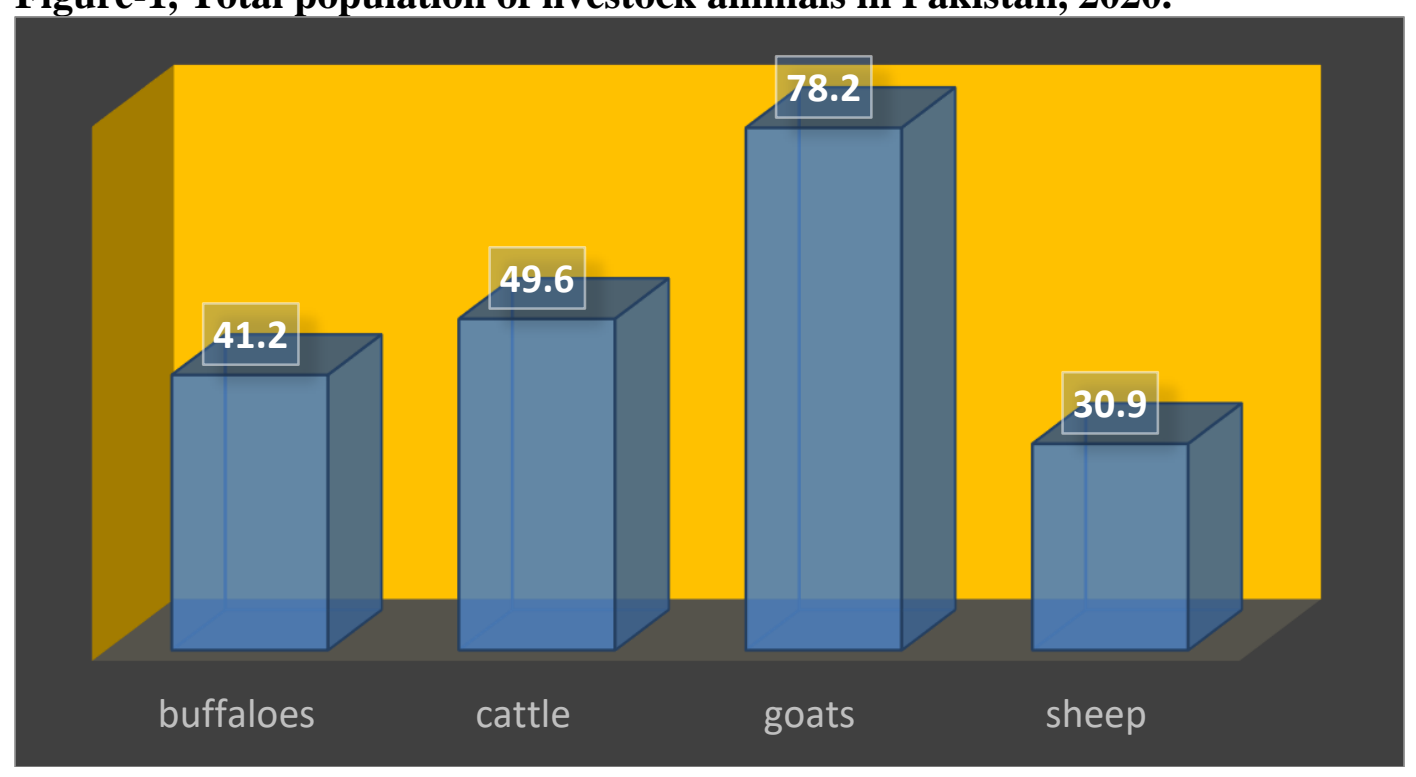




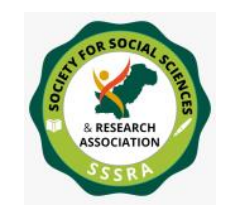

Pak. Journal of Int'L Affairs, Vol 4, Issue 3 (2021) Livestock Management Practices: Socioeconomic ...

The wool is obtained from the livestock animals. However, Pakistan exports huge quantities of wool from the different countries. The Sahiwal Breed and Red Sindhi cattle were the major breeds among the livestock animals. Therefore, milk and dairy production is widely used and obtained from these breeds. On the other hand, the animal dung is the major source for fuel and also used for soil fertilizers. Pakistan has the huge potential for the livestock sector. But unfortunately due to the poor planning, the livestock sector abandoned as a result the socio-economic condition of the rural farmers did not improve (Siddiqi, 1977; Encyclopedia of the Nations, 2011; and Wasim, 2020).

\subsection{Problem statement}

Balochistan is the biggest province of the country. Livestock and agriculture are the major occupations of the rural communities. Both sectors at the province level have huge potential. But due to the poor practices in the livestock sector the socio-economic condition of the rural masses did not improve. Keeping in view the importance of the livestock sector and livestock sector management practices as a major determinant in terms of socioeconomic impacts this research was carried out in Balochistan.

\subsection{Objectives}

1. To determine the biographic condition of the livestock farmers.

2. To find out the management practices as used by the livestock farmers for socio-economic improvement in study areas.

3. To develop result-based recommendations for policy makers regarding the livestock sector development and their socioeconomic impacts.

\subsection{Methodology}

A descriptive design was applied so that it obtained the views of livestock farmers (Levin, 1979; Miller, 1977; and Phillips, 1971). In this regard, two districts of Balochistan like Lasbela and Loralai were selected randomly (Ackoff, 1961; Allen, 1978; Barzun \& Graff, 1990; Best \& Kahn, 986). Three hundred livestock farmers selected in order to determine the livestock management practices within terms of socioeconomic impacts in Balochistan by using the random sampling (Bhattacharya, 1972; Burgess, 1960; and Chaturvedi, 1970). A questionnaire (closed-ended) in this regard was developed (Clover \& Balsley, 1984; Cochran, 1963; and Deming, 1980). Krejcie and Morgan (1970) table "sample size from a given population" were determined, .71 to .78 the range of Cronbach Alpha program. In this research the biographic information as independent variables and dependent variables as the general information (Sadhu \& Amarjit, 1990; and Sharma, 1998). Raw information 
was put into the SPSS. Non-parametric tests were used (Yamane, 1973 and Young, 1960). P-value set on five alpha levels by using the Pearson Chi-square test (Siegel, 1970; and Tondon, 1989).

\subsection{Study findings}

Biographic profile was the imperative aspect of this research. In this regard the raw data was gathered at field level so as to determine the livestock management practices within socioeconomic impacts at province level.

\section{Figure-2, Respondents age}

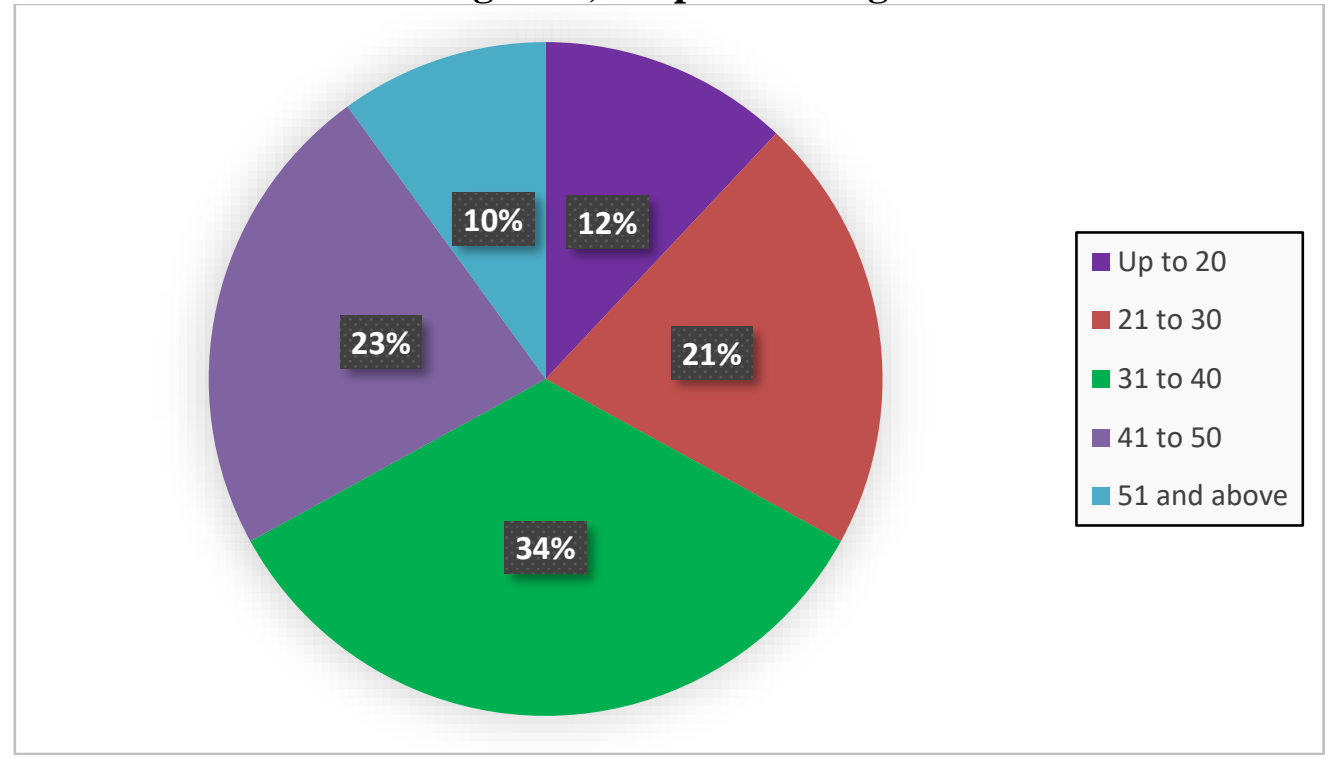

Age of the livestock farmers were the major demographic attribution. In this regard the data was gathered at field level so as to determine the perception of the respondents (figure-2). Most (34\%) of livestock farmers' age ranged into the 31 to 40 years. Whereas $23-21 \%$ of livestock farmers age ranged into the 41 to 50 and 21 to 30 years' categories respectively. On the other hand, only $12-10 \%$ of livestock farmers' ages ranged up to 20 and 51 above respectively.

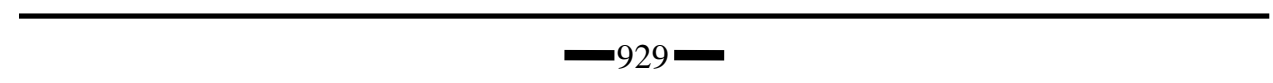


Pak. Journal of Int'L Affairs, Vol 4, Issue 3 (2021) Livestock Management Practices: Socioeconomic ...

Figure-3, Respondents educational position

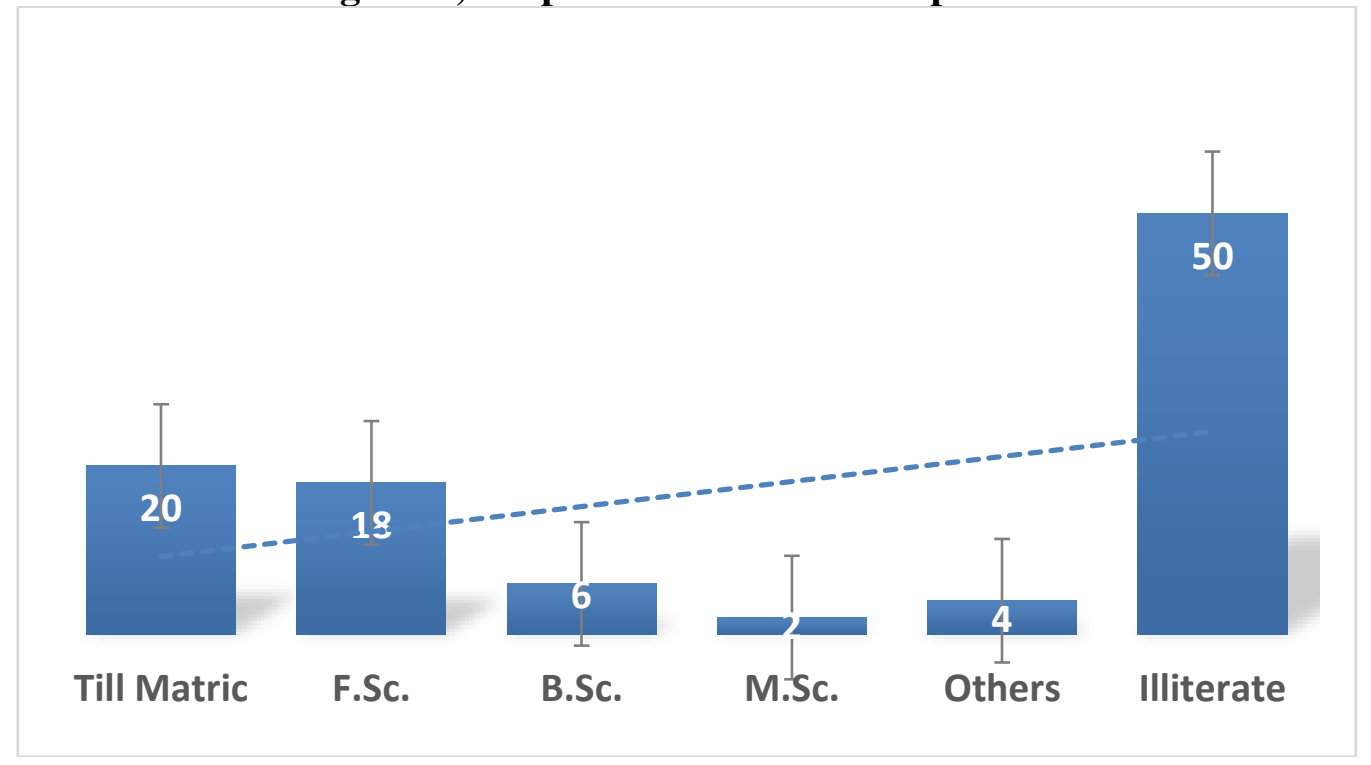

Education of the respondents in this regard as the major contributing demographic information. In this regard the facts and figures were gathered at field level from the livestock respondents so as to measure their perceived perception about their educational level as shown in figure-3. Half 50\% of the livestock farmers were illiterate and did not get their education from any formal institution. Whereas $20-18 \%$ of the farmers or respondents having the Matriculation or Intermediate level of education respectively. While only 6-4\% of the respondents were having B.Sc. and others like religious level of education respectively.

Figure-4, Respondents gender status

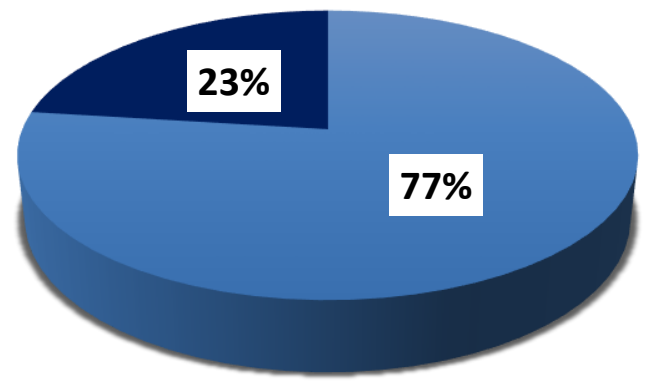

Male $\square$ Female 
When asked about the respondent's gender composition by using the comprehensive questionnaire, the vast majority $77 \%$ of the livestock respondents were of the view that by gender they were male. The remaining $23 \%$ of the respondents were by gender female. However, the female was contributing a huge contribution to the livestock sector in this regard.

Table-1, Socioeconomic impacts perceived score

\begin{tabular}{|l|c|c|c|}
\hline Livestock management practices & Value & df & \multicolumn{1}{|c|}{$\begin{array}{c}\text { Asymp: Sig. (2- } \\
\text { sided) }\end{array}$} \\
\hline Livestock socioeconomic impacts in district Lasbela \\
\hline Pearson Chi-Square & $14.374^{\mathrm{a}}$ & 4 & $\mathbf{. 0 0 6 N A}$ \\
\hline Likelihood Ratio & 14.832 & 4 & .005 \\
\hline Linear-by-Linear Association & 6.817 & 1 & .009 \\
\hline Phi & .219 & - & .006 \\
\hline Cramer's V & .219 & - & .006 \\
\hline Livestock socioeconomic impacts in district Loralai & $3.529^{\mathrm{a}}$ & 4 & $.474 \mathrm{NA}$ \\
\hline Pearson Chi-Square & 3.562 & 4 & .468 \\
\hline Likelihood Ratio & .046 & 1 & .830 \\
\hline Linear-by-Linear Association & .108 & - & .474 \\
\hline Phi & .108 & - & .474 \\
\hline Cramer's V & & \\
\hline $\begin{array}{l}\text { Valid Cases No. = "300" respondents } \\
\text { Significant at 5\% level }\end{array}$
\end{tabular}

Socioeconomic impacts in this was the major dependent variable. In this context, the raw information was gathered at field level as shown in table- 1 based on $(\mathrm{p} \leq 0.05)$ probability level. Chi-Square technique results revealed that there was statistically non-significant direction observed in both respected districts. Non-significant discrepancies were observed in both study districts. Though, results of Chi-Square values were non- significant in Lasbela district: $\left(\right.$ Chi-Square $\left.=14.374^{\mathrm{a}}\right)$, (Likelihood Ratio=14.832) and (Linear-by-Linear Association $=6.817)$ receptively at $(\mathrm{p} \leq 0.05)$ level. On the other hand, district Loraali: (ChiSquare $\left.=3.529^{\mathrm{a}}\right)$, $($ Likelihood Ratio=3.562) and (Linear-by-Linear Association=.046) was

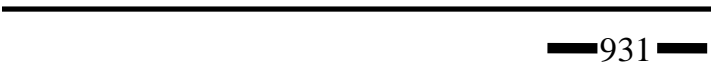


Pak. Journal of Int'L Affairs, Vol 4, Issue 3 (2021) Livestock Management Practices: Socioeconomic ...

found non-significant. Non-significant relationships between the variables were found regarding socio-economic impacts based on $(p<.05)$ alpha level.

\subsection{Summary and recommendations for policy implication}

This effort was examining the livestock management practices within terms of socioeconomic impacts in selected districts of Balochistan region so as to determine the technology importance in livestock sector at province level. In this aspect, livestock trends must be kept in the scientific line so as to improve the socio-economic condition of the rural farmers. Latest technologies related to the livestock sector must be prompted at province level. So as to improve the livelihood options of the respondent's adequate subsidy rate of animal fodders, animal medicines, animal shelters provided to the livestock farmers by the government. For the department adequate incentives should be given to the staff so that to increase the competency level of livestock department staff. Furthermore, the government should provide livestock farmers satisfactory information so as to give livestock farmers fair share in consumer prices and legitimate trade practices adopted. Livestock extension services in this regard disseminated modern animal husbandry practices to the livestock farmers. 


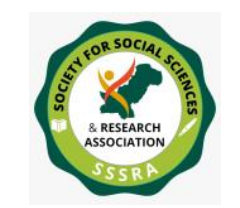

Pak. Journal of Int'L Affairs, Vol 4, Issue 3 (2021) Livestock Management Practices: Socioeconomic ...

\section{REFERENCES}

Ackoff, Russell, L. 1961. The Design of Social Research, University of Chicago Press: Chicago.

ADB, 1987. Livestock Sector Project. Technical Assistance to the Islamic Republic of Pakistan. Asian Development Bank, Manila.

ADB, 1989. Livestock Development Project in Islamic Republic of Pakistan. Report of the Board of Directors. Asian Development Bank, Manila.

Allen, T. Harrell, 1978. New Methods in Social Research, Praeger Publication: New York.

Asian Development Bank, 2004. Operations evaluation department in livestock development project in Pakistan. Asian Development Bank: Pak 21131.

Barzun, J. \& Graff. F. 1990. The Modern Researcher, Harcourt, Brace Publication: New York.

Best, J., W. \& Kahn, J. 1986. Research in Education, 5th ed., Prentice-Hall of India Pvt. Ltd. New Delhi.

Bhattacharya, S. 1972. Psychometrics \& Behavioral Research, Sterling Publishers Pvt. Ltd. New Delhi.

Burgess, E. 1960. Research Methods in Sociology, New York Philosophical Library: New York.

Chaturvedi, J., C. 1970. Mathematical Statistics, Nok Jonk Karyalaya: Agra.

Clover, V., T. \& Balsley, H., L. 1984. Business Research Methods, Grid, Inc. Columbus.

Cochran, W., G. 1963. Sampling Techniques, John Wiley \& Sons: New York.

Delgado, C. 2005. Rising demand for meat and milk in developing countries. implications for grasslands-based livestock production. Grassland a global resource, p. 29-39.

Deming, W., E. 1980. Sampling Designs in Business Research, John Wiley \& Sons. New York.

Encyclopedia of the Nations, 2011. Pakistan - Animal husbandry. Encyclopedia of the Nations. Retrieved 14 November 2011. 
Pak. Journal of Int'L Affairs, Vol 4, Issue 3 (2021) ～Livestock Management Practices: Socioeconomic ...

Krejcie, R.V., \& Morgan, D.W. 1970. Determining sample size for research activities . Educational and psychological measurement, 30, 607-610. Retrieved from http://home.kku.ac.th/sompong/guest.

Levin, R., I. 1979. Statistics for Management, Prentice-Hall of India Pvt. Ltd: New Delhi.

Meadowcroft, J. 2009. Minding the stock: bringing public policy to bear on livestock sector development.

Miller, D., C. 1977. Handbook of Research Design \& Social Measurement, 3rd ed., David Mckay Company, Inc: New Delhi.

Phillips, B., S. 1971. Social Research, Strategy and Tactics, 2nded., The Macmillan Company. New York.

Sadhu, A., N. \& Amarjit. 1990. Research Methodology in Social Sciences, Himalayan Publishing House. Bombay.

Sharma, B., A. 1998. Research Methods in Social Sciences, Sterling Publishers Pvt. Ltd. New Delhi.

Siddiqi, A., H. 1977. Some economic characteristics of animal husbandry in Pakistan. Afro-Asian Dry Belt. Geo Journal (1): 3-40.

Siegel, S. 1970. Nonparametric Statistics for the Behavioral Sciences, McGraw-Hill Publishing Co: New York.

Simon, J., L. 1980. Resources, population, environment: an oversupply of false bad news. Science; 208 (4451):1431-7.

Tondon, B., C. 1989. Research Methodology in Social Sciences, Chaitanya Publishing House. Allahabad.

Wasim, A. 2020. No change in population of camels, horses and mules". Retrieved 12 June 2020.

Yamane, T. 1973. Statistics: An Introductory Analysis, Harper and Row. New York.

Young, P., V. 1960. Scientific Social Surveys and Research, 3rd., Prentice-Hall: New York. 